Itinéraires Itinéraires

Littérature, textes, cultures

2010-4 | 2010

Modernités shakespeariennes

\title{
A Tempestuous Translation: Aimé Césaire's Une tempête
}

Philip Crispin

\section{(2) OpenEdition}

Journals

\section{Electronic version}

URL: http://journals.openedition.org/itineraires/1746

DOI: 10.4000/itineraires. 1746

ISSN: 2427-920X

\section{Publisher}

Pléiade

\section{Printed version}

Date of publication: 1 December 2010

Number of pages: 137-161

ISBN: 978-2-296-13183-5

ISSN: $2100-1340$

\section{Electronic reference}

Philip Crispin, "A Tempestuous Translation: Aimé Césaire's Une tempête », Itinéraires [Online], 2010-4 | 2010, Online since 19 September 2014, connection on 19 April 2019. URL : http:// journals.openedition.org/itineraires/1746 ; DOI : 10.4000/itineraires.1746

\section{(C) $(\oplus \Theta$}

Itinéraires est mis à disposition selon les termes de la licence Creative Commons Attribution - Pas d'Utilisation Commerciale - Pas de Modification 4.0 International. 


\title{
A Tempestuous Translation: Aimé Césaire’s Une tempête
}

\begin{abstract}
This article contends that Aimé Césaire's Une tempête (an anti-colonialist adaptation of The Tempest), epitomizes translation as interpretation and creative revision. With a striking fidelity to Shakespeare's play, Césaire engages with the racial and class conflicts intrinsic to The Tempest and gives voice to the occluded colonized and oppressed. Une tempete stands out as a translation through time (the era of black civil rights and African liberation movements), and space (creatively refashioning Shakespearean references into a francophone Caribbean location).
\end{abstract}

Keywords: Shakespeare, Césaire, translation, tempests, post-colonial Mots clés: Shakespeare, Césaire, traduction, tempêtes, post-coloniale

Caliban. - Prospero, tu es un grand illusioniste :

le mensonge, ça te connait.

Et tu m'as tellement menti, menti sur le monde, menti sur moi-même, que tu as fini par m'imposer une image de moi-même:

Un sous-développé, comme tu dis, un sous-capable, voilà comment tu m'as obligé à me voir, et cette image, je la hais! Et elle est fausse! Mais maintenant, je te connais, vieux cancer, et je me connais aussi! (88)

Caliban. - Prospero you're a great illusionist: you know all about lies.

And you lied to me so much, lied about the world, lied about yourself, that you ended up by imposing on me an image of myself: 
underdeveloped, in your words,

incompetent,

that's how you forced me to see myself,

and I hate that image! And it is false!

But now I know you, you old cancer,

And I also know myself! ${ }^{1}$ (58)

\section{Towards a Black Theatre}

The late Aimé Césaire (1913-2008) shall be forever associated with the philosophy of negritude that he espoused with such impact on the francophone black world from the 1930s on. Negritude re-appropriated the word nègre with its insulting connotations. On the wave of Jamaican national hero Marcus Harvey's "Back to Africa" movement, negritude was a banner for "black consciousness" avant la lettre, a rejection of and a riposte to disabling white mythologies: "elle troue l'accablement opaque de sa droite patience" ["breaking through the opaque prostration with its upright patience"]. ${ }^{2}$ It straddled both a political project and a poetic renewal, confronting the violence of colonialism with cataclysmic passion: "the striking of the mental wave against the rock of the world." Negritude sought to "decolonize the mind" and Césaire's poetry is a cry to revolt, intransigent in its fidelity to the "invulnerable idea" of justice - and shot through with pain at the tragedy of its non-realisation.

The Gate Theatre in Notting Hill, London, is a small space above a pub which exists on slender means. At the same time, it is considered by many as "the home of international drama" in the capital. I became the Gate's literary manager in 1998. The then artistic team conceived of the Gate as an arena of spiritual liberation and an enriching crucible of cultures: a gateway to a richer knowledge of the human. I believed that these themes lay at the heart of Césaire's great anti-colonialist adaptation of The Tempest which he entitled Une tempete (the lower case $\mathrm{t}$ is no accident; here Shakespeare's island play is cut down to size; this tempest is one colonial storm among many). As the vanguard production for our Home for the Exiles season in 1998, I advocated staging this play to mark the $150^{\text {th }}$ anniversary of the abolition of slavery in the French colonies and the $50^{\text {th }}$ anniversary of the arrival of the first wave of post-war immigrants from the West Indies to Britain on board the S.S. Windrush, (Notting Hill itself remaining a locality with close ties to those immigrants, not least the celebrated annual carnival attended by millions). We would commemorate

1. Citations throughout are from Aimé Césaire, Une tempête, Paris, Seuil, 1969, and from my translation, Philip Crispin, A tempest, London, Oberon, 2000. Page numbers for both follow in parentheses.

2. From Aimé Césaire, Cahier d'un retour au pays natal, Paris, Présence Africaine, 1956. 
those momentous events in what was to be a critically acclaimed British première and I provided a new translation of the play for this purpose. ${ }^{3}$

\section{Tempestuous Translations}

Une tempête was already well known within the francophone world. ${ }^{4}$ First produced at an international festival in Hammamet, Tunisia, in the summer of 1969, before playing in Paris in January 1970, it was directed by Jean-Marie Serreau, with whom Césaire had worked so closely on most of his theatrical writing. Serreau's death in 1973 brought Césaire's career as a playwright to a close. ${ }^{5}$ That first production is of special interest: a Caribbean rewriting of The Tempest, produced in Tunisia, close to Sycorax's origins and to Claribel's destiny (though neither, interestingly, feature much); which reads the play in part through the US black politics of the Civil Rights period (associating Caliban with Malcolm X and Ariel with Martin Luther King), and which adopted the manners and dress of an American Western. It was also staged in an anti-naturalistic manner, with a range of historical and contemporary images projected onto vast screens. Another notable production was that by Elie Pennont in Martinique in 1992, where the actor playing the African god Eshu became the unifying image, remaining on stage throughout the performance (in Césaire's script he appears in one scene only), watching silently from a distance: "the incarnation of the fragmented psyche that must be acknowledged before any healing can take place."

Césaire's single point of attachment to Shakespeare's play is to be found in Act III Scene 2 when Caliban declares: "I am subject to a tyrant, a sorcerer that by his cunning hath cheated me of the island." Subtitled "an

3. A tempest (Une tempête) played from 21 September to 14 October, 1998. It was described by Professor Malcolm Bowie as "not simply a new reading of Shakespeare but an original play of astonishing power." Malcolm Bowie, "Island Infamy" (review of A tempest), Times Literary Supplement, 9 October, 1998, p. 22.

4. I am indebted to Peter Hulme and Bill Sherman for the stage history in this paragraph. Their co-edited book "The Tempest" and its Travels, published by Reaktion Books in 2000, is a rich cultural study of The Tempest, exploring, among other concerns, its vitality in new contexts, its key significance in colonial and post-colonial debates, and its problematising of the movement between the local and the global. It includes two scenes from my translation and two photographs by Pau Ros from the London production, as well as an article by Lucy Rix: "Maintaining the State of Emergence/y: Aimé Césaire's Une tempête."

5. See Robert Eric Livingston, "Decolonizing the Theatre: Césaire, Serreau and the Drama of Negritude," in J. Ellen Gainor (ed.), Imperialism and Theatre: Essays on World Theatre, Drama and Performance, London, 1995, p. 182-98.

6. See Alvina Ruprecht, "Staging Aimé Césaire's Une tempête: Anti-Colonial Theatre in the Counter-Culture Continuum," Essays in Theatre/Études théâtrales, vol. 15, n 1, 1996, p. $59-68$, p. 62 .

7. Of course, it is true that in The Tempest, Sycorax and Caliban also colonised the island and supplanted its original inhabitants, too. Evidently, Césaire's polemical adaptation provides a 
adaptation for a black theatre," Une tempête engages with the fundamental racial and class elements intrinsic to The Tempest, with the implicit intention of wresting the adapted play away from the negative and complacent agenda of an institutionally racist imperial theatre. Césaire's powerful transformative project is underpinned by radical historical revisionism. Speaking about Shakespeare's play, he said:

Demystified, the play [is] essentially about the master-slave relation, a relation that is still alive and which, in my opinion, explains a good deal of contemporary history: in particular, colonial history, the history of the United States. Wherever there are multiracial societies, the same drama can be found, I think. ${ }^{8}$

\section{According to Helen Gilbert and Joanne Tompkins:}

For generations during (and often after) imperial rule, the formal education of colonial subjects was circumscribed by the concerns and canons of a distant European centre. Because of its supposed humanistic functions, "English [and French] Literature" occupied a privileged position in the colonial classroom, where its study was designed to "civilise" native students by inculcating in them British [and French] tastes and values, regardless of the exigencies of the local context. ${ }^{9}$

Lucy Rix describes the dominant "traditional" French literary production which prevailed during Césaire's childhood and which became one of the first targets identified in Légitime Défense (1932), "a journal published by a

partial reading of the original script. His focus is on the (formerly) enslaved black diaspora. Intriguingly, however, in his droll re-working of Caliban's encounter with Stephano and Trinculo, the recalcitrant butler and jester still refer to him as an Indian or, more often, a "nindian." This word possesses a double resonance. Firstly, it recalls the original inhabitants of the "New World," vast numbers of whom were wiped out due to conquerors' genocides, inhuman treatment or because their immune system was unable to protect them against newly imported diseases. In Césaire's play, Stephano and Trinculo still intend to display Caliban in a travelling fair as an exotic "freak" when back home. Secondly, "nindian" evokes West Indian, the collective name for anglophone Caribbean inhabitants, so called because Christopher Columbus had dubbed the indigenous people he found Indians, for he believed that he would be able to reach the Indies by sailing west. Since the period of slavery, of course, the majority of "West Indians" are descended from the African diaspora. It is important to note that, with the exception of the list of dramatis personce in which Caliban is identified as a savage slave, it is Trinculo who, in Act II Scene 2, categorically registers Caliban's humanity, calling him an "islander," and also how in England "would this monster make a man." He and Stephano generally refer to him in pejorative dehumanising terms (eg "mooncalf"), however.

8. Quoted in Livingston, op. cit., p. 192.

9. Helen Gilbert and Joanne Tompkins, Post-Colonial Drama: Theory, Practice, Politics, London and New York, Routledge, 1996, p. 15. Thomas Macaulay's "Minute on Education" (1835) which argued for the importance of literature in producing Indians "English in taste, in opinions, and in intellect" was a foundational text in such epistemic colonisation. 
group of Martiniquan students at the Sorbonne that would have a profound impact on their cultural identity":

The West Indian writer, stuffed to bursting with white morality, white culture, white education, white prejudice, fills his little books with a swollen image of himself. Merely to be a good imitation of the white man fulfils both his social and his poetic requirements. He cannot be too modest or too sedate. Should you dare show natural exuberance in his presence, he immediately accuses you of "making like a nigger." So naturally, he does not want to "make like a nigger" in his poems. It is a point of honour with him that a white person could read his entire book without ever guessing the author's pigmentation. ${ }^{10}$

Césaire pokes some well-informed fun at this colonial education and specifically when it focuses upon the exotic Other. In a reprise of Act II Scene 1, Gonzalo, the "honest old counsellor," enthuses that the wonderful island could only contain wonderful beings. Antonio drily concurs and cites Baudelaire's "Parfum Exotique" in Les Fleurs du Mal:

Des hommes dont le corps est mince et vigoureux

Et des femmes dont l'æil par sa franchise étonne..

Men whose bodies are slender and strong

And women whose frank stares astound... ${ }^{11}(29)$

Gonzalo enthusiastically endorses this view and adds, "Je vois que vous connaissez vos auteurs" (40) ["I see you know your authors" (29)].

Martinique is still politically part of metropolitan France. Aimé Césaire was thus a French citizen and politician. Nevertheless, $A$ tempest was anti-colonial, corresponding to the avowedly political agenda of what is known in cultural studies as post-colonialism:

to dismantle the hegemonic boundaries and the determinants that create unequal relations of power based on binary oppositions such as "us and them," "first world and third world," "white and black," "coloniser and colonised." [...] Post-colonial texts embrace a more specifically political aim: that of the continued destabilisation of the cultural and political authority of imperialism. ${ }^{12}$

During the period of de-colonization in the middle of the last century, Une tempête contributed to an increasing and ongoing re-evaluation of canonical

10. Lucy Rix, "Maintaining the State of Emergence/y: Aimé Césaire's Une tempête," in Peter Hulme and Bill Sherman, op. cit., p. 236-249, p. 239. Quotation from Légitime Défense taken from Lilyan Kesteloot, Black Writers in French, trans. Ellen Conroy Kennedy, Philadelphia, Temple University Press, 1974.

11. In our production in London, we replaced Baudelaire with Miranda's line: “O brave new world, that hath such creatures in it!" which always received a good laugh.

12. Gilbert and Tompkins, op. cit., p. 3. 
literary texts, and Shakespeare's The Tempest attracted particular interest from intellectuals and writers from various colonial domains throughout the African diaspora. Many chose to focus on The Tempest because of the play's prototypical colonial narrative: the story of a European who disembarks onto an already-occupied island to presume ownership of the land and control over the inhabitants. According to Gilbert and Tompkins:

The Tempest remains the text most widely chosen for counter-discursive interrogations of the Shakespearian canon. A number of factors account for this choice: the play's figuration of racial binaries and the threat of miscegenation; its representation of the New World "other" as opposed to the European "self," troped as a form of the nature/culture dichotomy; and its pervasive interest in power relationships involving dominance, subservience, and rebellion. ${ }^{13}$

Furthermore, from the perspective of writers in the Caribbean and Africa, what better target for appropriation than the Bard, the paragon of British cultural hegemony? ${ }^{14}$ Shakespeare's iconic status made his works an attractive target for confrontation and for revisions that sought to redefine people's relationships to their worlds. What is at stake is, according to Rob Nixon, "the very possibility of decolonising the area's cultural history by replacing an imposed with an endemic line of thought and action." ${ }^{\prime 5}$ These Caribbean and African writers found in Caliban a figure richly evocative of their condition. They adopted the play as a rallying and foundational text, rich for revision and re-appropriation, and they appreciated that The Tempest could bolster their self-definition during a time of major upheaval:

for the figure of Caliban - marginalized and virtually imprisoned on the island, presumed to have been culturally illiterate before the Europeans' appearance, and alienated from his own sense of self through linguistic and physical control - was a dramatic reflection of an all-too-familiar experience. ${ }^{16}$

Yet it is important to recall, like Paul Brown, that "The Tempest is not simply a reflection of colonialist practices but an intervention in an ambivalent and even contradictory discourse." 17 Brown considers

13. Ibid., p. 25.

14. See Ibid., p. 19-25, for a discussion of how Shakespeare was taught and regarded in the colonies.

15. Rob Nixon, "Caribbean and African Appropriations of The Tempest," Critical Inquiry $\mathrm{n}^{\circ} 13,1987$, p. 569.

16. See Gilbert and Tompkins, op. cit., p. 30-31.

17. Paul Brown, “'This Thing of Darkness I Acknowledge Mine': The Tempest and the Discourse of Colonialism," in Jonathan Dollimore and Alan Sinfield (eds.), Political Shakespeare: New Essays in Cultural Materialism, Manchester, Manchester University Press, 1985, p. 48-71, p. 48. 
Shakespeare's play a narrative "which seeks at once to harmonize disjunction, to transcend irreconcilable contradictions and to mystify the political conditions which demand colonialist discourse," but he writes the play "ultimately fails to deliver that containment and instead may be seen to foreground precisely those problems which it works to efface or overcome."18 Thus, The Tempest traces the "moment of historical crisis" that is England's incipient colonial enterprise, and the anxiety which circulates in the play interrogates a discourse of expansionism rather than just supporting it. ${ }^{19}$ This interrogation of text and historical context is continued by Francis Barker and Peter Hulme who note the underlying anxiety in a play "imbricated within the discourse of colonialism." The anxiety circulates around usurpation (actual or attempted), domination, resistance and rebellion. Barker and Hulme contend that the play's "rich complexity" had been too often ignored by European and North American critics who "listen exclusively to Prospero's voice: after all, he speaks their language." (Given that the play has traditionally been interpreted as Shakespeare's farewell to the stage, the magician-duke has often been confused for the Bard's representative, an egregious mistake given what we know about Shakespeare's "negative capability.") They astutely noted: "It has been left to those who have suffered colonial usurpation to discover and map the traces of that complexity by reading in full measure Caliban's refractory place in both Prospero's play and The Tempest." ${ }^{20}$

Simply and provocatively put, if Shakespeare, as projected in a simplistic and authoritative imperial reading, provides an official, colonial perspective, Césaire - with astonishing fidelity to the original translates this and gives voice, specifically through Caliban, to the occluded colonized and oppressed. Une tempête epitomizes translation as interpretation, as (creative) revision. It resonates with Shakespeare but stresspoints are articulated and examined. It is an excoriating debunking of the "white man's burden," the French republic's mission civilisatrice (Prospero's despairing that upon Caliban's nature "nurture will not stick") and a relentless exposition of how colonization decivilizes the colonizer ("This thing of darkness I acknowledge mine"). The infamy of colonial exploitation is recognised and named. In his Discourse on Colonialism, Césaire initially defines colonization in negative terms, by first of all establishing what it is not: "neither evangelization, nor a philanthropic

18. Ibid., p. 48.

19. Although there had been Cambro-Norman-English colonising of Ireland since the twelfth century, this became concerted in the sixteenth century. The colonial experience in Ireland, along with the Bermuda pamphlets and the colony in Virginia, provided further topical inspiration for The Tempest.

20. Francis Barker and Peter Hulme, “'Nymphs and Reapers Heavily Vanish': The Discursive Con-texts of The Tempest," in Jonathan Drakakis (ed.), Alternative Shakespeares,London and New York, Methuen, 1985, p. 191-205, p. 204. 
enterprise, nor a desire to push back the frontiers of ignorance, disease and tyranny, nor a project undertaken for the greater glory of God, nor an attempt to extend the rule of law." ${ }^{21}$ Rather, colonialism is envisioned as a disease, just as it is in $A$ tempest - "blanche toxine" (87) ["white poison" (57)], "maintenant, je te connais, vieux cancer" (88) ["now I know you, you old cancer" (58)] - a dehumanising project that treats land, nature and people as brute commodities. It must be vomited out. ${ }^{22}$

In Act II Scene 2, Gonzalo says:

Si l'île est habitée, comme je le pense, et que nous la colonisons, comme je le souhaite, il faudra se garder comme de la peste d'y apporter nos défauts, oui, ce que nous appelons la civilisation. Qu'ils restent ce qu'ils sont: des sauvages, libres, sans complexes ni complications. Quelque chose comme un réservoir d'éternelle jouvence où nous viendrions périodiquement rafraîchir nos âmes vieillies et citadines. (40-41)

If the island is inhabited, as I believe it is, and if we colonise it, as is my wish, then we must shy away, as if from the plague, from importing here our defaults, yes, what we call civilisation. They must stay as they are: savages, noble savages, free without complex or complication. Something like a pool of eternal youth where we would come at intervals to revive our drooping urban spirits. ${ }^{23}(30)$

With a piercing satirical economy, Césaire alludes to Gonzalo's utopian rhapsody in The Tempest, with its indebtedness to Thomas More, Montaigne and the classical theory of the Golden Age, but what is most striking is how Césaire picks up on Montaigne's ethical denunciation of western inhumanity and brutality in "Of Cannibals." This was a key reference point for a developing, idealized argument in favour of the rights of indigenous peoples throughout the early modern period and into the Age of Reason. In the sixteenth and seventeenth centuries, the "good savage" was held up as a reproach to European civilisation in the throes of the wars of religion, and stood as a direct counter to the Hobbesian view of human depravity in a state of nature. By the eighteenth century, this argument was fuelled by both sentimentalism and primitivism, and was advanced

21. Aimé Césaire, Discourse on Colonialism, Trans. Joan Pinkham, New York, Monthly Review Press, 2000, p. 32.

22. The Discourse on Colonialism compares the evils of imperialism with the evil of the Holocaust, the difference being that in the former case the evils went largely unchronicled and uncondemned. Caliban says at the climax of the play: "Te vomir. Toi, tes pompes, tes œuvres! Ta blanche toxine!" (87) ["I'd vomit you up, all your pomp and designs! Your white poison!" (57)].

23. Gonzalo's idyll-manifesto chimes with the type of clichés trotted out during an exhibition on "The Happy Antilles" held in Paris in 1945 by the Ministry of Colonies. Poems included described Martinique as an enchanting "Paradis végétaux," a "Coffre à baisers" and a "Cher jardin des petits cadeaux," a "Familière boîte à surprise." Cited in Rix, op. cit., p. 306. 
by both English and French writers and explorers. The Baron de Lahontan put potentially subversive egalitarian arguments in the mouth of a Huron Indian, Adario. Jean-Jacques Rousseau, identified as the philosopher of the French Revolution, was deliberately maligned by his political opponents for advancing a theory about the "noble savage" but this was untrue. What is clear, however, is how such a theory preserved a superior paternalism and ultimately a lack of egalitarian empathy between the colonisers and the colonised in which the latter were cast as dependent children - here "a pool of eternal youth." Prospero calls Caliban "boy" (a repugnant name for colonial servants) at the very end of $A$ tempest. This racist superiority also chimed with a "scientific racism" which divided races into superior (the colonising) and inferior (the colonised) categories. ${ }^{24}$

The other key theme to pick up in this re-casting of Act II Scene 2, is the duplicity within Gonzalo's sugared and idealistic words. He freely admits that he favours colonisation, but his eulogy of the "noble savages," whom he wishes to preserve as they are, as if in aspic, is undermined by his simultaneous desire to plunder the island for its natural resources, "guano" in this case, which, "sous une sage direction" (39) ["wisely administered" (29)], will make the island "plus riche que l'Égypte avec son Nil" (39) ["richer than Egypt with its Nile" (29)]. Césaire identifies a base rapaciousness underlying both the colonial and the neo-colonial project in which, say, the generally environmentally disastrous plunder of natural resources would be carried out by the colonisers - or multinational companies, in many ways their modern equivalents - with virtually none of the profits benefiting the local population, whilst literally dismantling the topography, and cultural topography, beneath their feet. ${ }^{25}$

24. The phrase "noble savage" first appeared in Dryden's play The Conquest of Granada (1672) although it may have been inspired by a 1609 travelogue about Canada by the French explorer Marc Lescarbot who wrote that the "savages are truly noble," although this was because they, like French royalty, hunted game. Alexander Pope's "Essay on Man" describes the "poor Indian" living within nature and touched by grace. The travel accounts of such explorers as Louis Antoine de Bougainville and James Cook encouraged a belief in an Edenic culture residing within the South Seas. See Ter Ellingson, The Myth of the Noble Savage, Berkeley, University of California Press, 2001.

25. In Une tempête, Prospero tells Miranda how his prophetic art had "discovered" the precise location of those lands which had been sought for centuries. His brother Antonio and rival King Alonso of Naples conspire to depose him and steal his "empire à naître" (20) ["unborn empire" (16)]. This fascinating addition to the plot calls to mind the great powers' "scramble for Africa" in the nineteenth century and other such contests for territorial domination. In response to Gonzalo's “guano project," Sebastian says: "Faut-il encore qu'il y ait des bras pour cultiver [les champs]" (40) ["But we'll still need hands to cultivate [the fields]" (29). Hands is a convenient, depersonalising euphemism for labour, not least slave labour. Gonzalo's "plantation" in The tempest leads inevitably to the thoughts of slave plantations - across the Caribbean, the American tropics (North, Central and South) and Africa where King Leopold's rubber plantation in the Congo led to Joseph Conrad's memorable phrase: "the heart of darkness." 
As Caliban says to Prospero: "Tu crois que la terre est chose morte... C'est tellement plus commode! Morte, alors on la piétine, on la souille, on la foule d'un pied vainqueur!" (25-6) ["You think the earth itself is dead... It's so much more convenient! Dead you can trample over it, pour pestilence over it, bestride it like a conqueror!" (20)] Césaire adds another element to the neo-imperialist project: tourism. Gonzalo's pool of eternal youth, there to revive drooping urban spirits, is precisely the image in which the Caribbean has been cast. Once again, the inhabitants, here of the islands, are cast in belittling and servile roles, in order to service the fantasies of their western paymasters. Such fantasies home in on subpastoral, primitivist clichés concerning a proximity to nature (even if the islanders' natural environment is destroyed), spontaneity, creativity and straightforward sexuality and eroticism.

\section{Uhuru}

Knowledge contains the seeds of transformative power: language shapes how we think and therefore how we act. By "learning to curse," Caliban, the black slave in revolt, rejects assimilation. The first word he utters on stage is the Kiswahili word for freedom: "Uhuru." Whereas for Shakespeare, Caliban is "a salvage and a deformed slave," Césaire's charismatic protagonist crucially uses a foreign language - foreign from the perspective of the colonizer, that is - in order to assert his own identity and autonomy. ${ }^{26} \mathrm{He}$ refuses to be interpellated as the linguistic subject of the colonial master narrative; he refuses to be broken and conditioned, a mere component in the means of production.

Steve Almquist writes that, "At the centre of Césaire's revision of Shakespeare's The Tempest is a single deeply resonant word - Uhuru. [...] Uhuru is essential to Césaire's revisionary project because it gives Caliban a voice, specifically an African voice, and it contributes to Césaire's overall project in creating a diasporic textual counter to Shakespeare."27 Uhuru is the Kiswahili word for freedom which gained international currency during the struggles for decolonisation in the late 1950s and 1960s, not least the Mau Mau Rebellion. Uhuru became a touchstone that recalled

26. Cf the OED's definition of pidgin: "any combination and distortion of two languages as a means of communication." Caliban communicates his otherness. According to Alan Lawson and Chris Tiffin: “'Difference,' which in colonialist discourse connotes a remove from normative European practice, and hence functions as a marker of subordination, is for post-colonial analysis the correspondent marker of identity, voice, and hence empowerment." Alan Lawson and Chris Tiffin, "Conclusion: reading difference," in C. Tiffin and A. Lawson (eds.), De-Scribing Empire: Post-Colonialism and Textuality, London, Routledge, 1994, p. $230-235$, p. 230.

27. Steve Almquist, "Not Quite the Gabbling of 'A Thing Most Brutish': Caliban's Kiswahili in Aimé Césaire's A tempest," Callaloo, vol. 29, n² 2, 2006, p. 587-607, p. 587-588. 
and rekindled the revolutionary fervour when the cry for freedom from colonial oppression was heard all over the world. ${ }^{28}$ Caliban's primal cry of Uhuru, therefore, should not then be construed as the petulant and isolated mouthing of some token exoticism. It is nothing other than a call to militant solidarity among the dispossessed, and specifically the dispossessed among the African diaspora. (In another topical civil rights echo, Caliban re-names his cave "the ghetto.") Almquist adds that:

During the often-tumultuous independence and Black Power movements throughout the African diaspora during the 1960s and 1970s, the use of Kiswahili among non-native writers and speakers expanded and came to serve as a symbolic resistance to the presumed supremacy of the European cultures and languages. ${ }^{29}$

Consider further the importance of Caliban's Kiswahili voice through which he voices his agitation at Prospero's domination. As Steve Almquist acutely appreciates, Césaire's empowered Caliban does not gabble like "a thing most brutish," unaware of his "own meaning" until taught the colonial language..$^{30}$ On the contrary, even before his black slave's first entrance, Prospero betrays his unease that Caliban "s'émancipe un peu trop" (24) ["is becoming a little too liberated" (18)].

28. Almquist warns that the word should not be understood in a monolithic way. Much of the western media demonised and sensationalized the Mau Mau as savage, primitive and anti-Christian, hence the word for many whites raised a frisson of anxiety and fear. "Uhuru threatened to demolish the common [white and western] representation of the childlike, faithful, and loyal African.” Ibid., p. 587. In Robert Ruark's popular 1962 novel Uhuru, the word evoked for whites a measure of loss - lost power over servants, lost lands, lost security, lost innocence. At the same time it identified Africans as bestial and depraved. "In a sense," Almquist adds, "Ruark is recasting Shakespeare's The Tempest and offering a twentieth-century version of the depraved slave in need of 'civilizing."” Ibid., p. 601. At the same time, there was a burgeoning attraction to the concept and linguistic power of Uhuru for those who might feel like modern-day Calibans themselves. Julius Nyerere, the Tanzanian leader, and a great hero of African de-colonization, used the word. According to Steven Feierman, "Gender, Slavery and Chiefship: Peasant Attempts to Create an Alternative Discourse," in Peasant Intellectuals: Anthropology and History in Tanzania, Madison, University of Wisconsin Press, 1990, p. 204-222, p. 212, cited by Almquist, "When older people heard Nyerere talk about Uhuru, 'freedom' or 'independence,' they also knew Uhuru in their observed experience as the release from utung'wa, 'slavery' or "pawnship,' which in their thinking presupposed an entire system of descent-group rights in persons." Almquist writes: "At the same time Uhuru would resonate as a symbolic slogan for overcoming racial oppression worldwide, in East Africa it carried with it the literal sense of freedom from a system of slavery." Césaire may or may not have been aware of this further resonance. Almquist, Ibid., p. 605. For a more expansive discussion of Uhuru, See Almquist, Ibid., p. 598-601.

29. Almquist, Ibid., p. 587.

30. Ibid. See p. 597. 


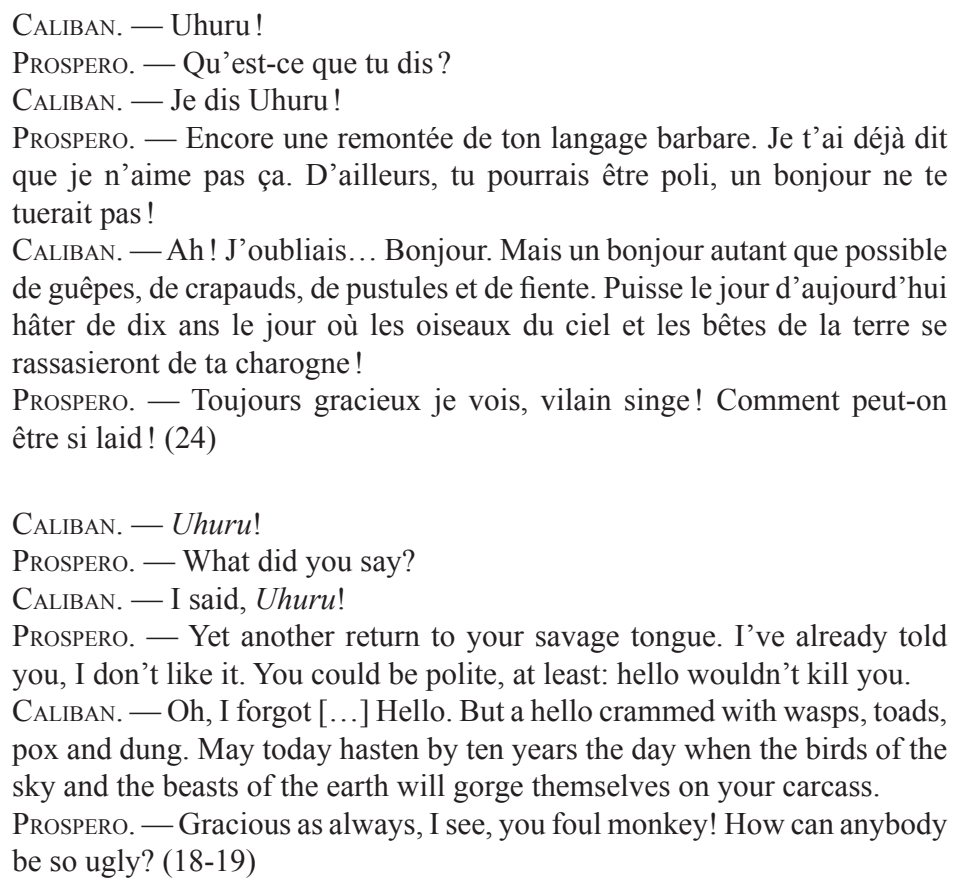

Attention focuses immediately on the power of language in defining their relationship. "Uhuru!" confounds Prospero's sense of linguistic authority; his only recourse is to demonize the word as a reversion to Caliban's "savage tongue" - in a classic rehearsal of a colonial "civilized/brute savage" binary - before continuing in the same vein:

Puisque tu manies si bien l'invective, tu pourrais au moins me bénir de t'avoir appris à parler. Un barbare ! Une bête brute que j'ai éduquée, formée, que j'ai tirée de l'animalité qui l'engangue encore de toute part! (25)

Since you spout invective with such aplomb, you might at least give me your blessing for having taught you to speak at all. A savage! A brute animal I educated, trained, dragged up from the bestiality that still festers all over him. (19)

In further disabling strategies, Prospero refuses to accept the validity or sense of Caliban's own culture and fashions Caliban as a sub-human beast in a manner which entirely honours such references as "freckled whelp" and "mooncalf" in The Tempest, the "savage and deformed slave" "upon whose nature nurture will not stick." 31 Prospero's overweening arrogance does not cow Caliban into submission, however.

31. "Freckled" refers to Caliban's skin colour. Césaire's use of the notoriously racist term of abuse "monkey" responds acutely to such a derogatory description. 
Caliban. - D'abord ce n'est pas vrai. Tu ne m'as rien appris du tout. Sauf, bien sûr à baragouiner ton langage pour comprendre tes ordres : couper du bois, laver la vaisselle, pécher le poisson, planter les légumes, parce que tu es bien trop fainéant pour le faire. Quant à ta science, est-ce que tu me l'as jamais apprise, toi? Tu t'en es bien gardé! Ta science, tu la gardes égoïstement pour toi tout seul, enfermée dans les gros livres que voilà. (25)

Caliban. - That's just not true. You haven't taught me anything at all! Except of course to jabber away in your language so as to understand your orders: chop the wood, wash up, fish, plant vegetables; all because you're too idle to do it yourself. As for your knowledge, did you ever impart any of that to me? You took care not to. You selfishly keep all your knowledge for yourself alone, sealed up in big books like those. (19)

Césaire's protagonist registers his acute understanding of how his "education" has achieved little more than to reduce him to subservience in the guise of an automaton-drudge (remember Césaire's formula: "colonisation $=$ thingification" ${ }^{32}$ ). At the same time, Prospero has kept from Caliban any life-enhancing (textual and scientific) knowledge - the key to his domination and an inspired riff on the magic books valued at more than Prospero's dukedom. Caliban ruefully reflects on how he has been an expendable and unvalued means to an end, hoodwinked by an initially friendly-seeming Prospero:

Qu'aurais-tu fait sans moi, dans cette contrée inconnue? Ingrat! Je t'ai appris les arbres, les fruits, les oiseaux, les saisons, et maintenant je t'en fous... Caliban la brute! Caliban l'esclave! Recette connue! l'orange pressée, on en rejette l'écorce! (26)

What would you have done without me in this strange land? Ungrateful! I taught you the trees, the fruits, the birds, the seasons, but there's no blessed question of that any more... Caliban the brute, Caliban the slave! I know the score! Once the orange is squeezed, the peel is tossed away! (20)

Note here, how it is Caliban, rather than Prospero, who is doing the teaching, yet this education, vital as it is, is subsequently given neither credit nor recognition.

Clearly, Caliban is cast as a figurative Malcolm X, even telling Prospero as he prepares to leave at the end of their first encounter in the play, that he will no longer answer to the name of Caliban:

Caliban. - [...] J'ai décidé que je ne serai plus Caliban.

ProsPero. - Qu'est-ce que cette foutaise? Je ne comprends pas!

Caliban. - [...] Caliban n'est pas mon nom. C'est simple!

Prospero. - C'est le mien peut-être!

32. Césaire, op. cit., p. 42. 


\begin{abstract}
Caliban. - C'est le sobriquet dont ta haine m'a affublé et dont chaque rappel m'insulte.

Prospero. - Diable! On devient susceptible! Alors propose... Il faut bien que je t'appelle! Ce sera comment? Cannibale t'irait bien, mais je suis sûr que tu n'en voudras pas! Voyons, Hannibal! Ça te va! Pourquoi pas! Ils aiment tous les noms historiques!

Caliban. - Appelle-moi X. Ça vaudra mieux. Comme qui dirait l'homme sans nom. Plus exactement, l'homme dont on a volé le nom. Tu parles d'histoire. Eh bien ça, c'est de l'histoire, et fameuse! Chaque fois que tu m'appeleras, ça me rappellera le fait fondamental, que tu m'as tout volé et jusqu'à mon identité! Uhuru!
\end{abstract}

Il se retire. $(27-28)$

Caliban. — [...] I've decided I'll be Caliban no longer.

Prospero. - What kind of bilge is this? I don't understand.

Caliban. - [...] Caliban isn't my name. It's simple!

Prospero. - It's mine, I suppose!

CALIBAN. - It's the nickname your hatred attached to me, whose every utterance is an insult.

Prospero. - My, how sensitive we've become! Well then, suggest another... I must call you something. What will it be? Cannibal would suit you well, but I'm sure you wouldn't want it! Let's see...Hannibal! Why not? They all like historical names!

Caliban. - Call me X. That's best. Like a man without a name. Or, more precisely, a man whose name was stolen. You speak of history. Well that's history, known far and wide! Every time you'll call me that will remind me of the fundamental truth that you stole everything from me, even my identity! Uhuru! (He exits.) (21-22)

Even if audience members are ignorant of the meaning of this Kiswahili word, they will understand that it has a key galvanizing importance, that it is Caliban's rallying cry and that it's very foreignness underlines his sense of an autonomous cultural "otherness," dignity and agency so brazenly denied him by Prospero. It is a call to revolution.

As ever, Césaire condenses Shakespeare's play with unerring cogency in order to provide the pith for his own agenda. Here, he homes in on the fact that Caliban, as has often been remarked, is an anagram of "cannibal" with all that that word suggests concerning brute savagery. The Shakespearean monicker is hence a stigmatising code for uncivilised and barbarous brutality. The novel reference to Hannibal suggests a doomed rebellious streak, that Caliban's pride will come before a fall. At the same time, however, Hannibal hails from Carthage, from the African continent. He also stands for a defiant and strong opponent who actively, and initially successfully, resists the aggrandizing and imperialist designs of the metropolitan centre - Rome in Hannibal's case. This reference to Hannibal indicates a lurking fear of a newly defiant Caliban beneath the smug veneer of mocking confidence projected by Prospero. This defiance, of course, chimes with the new confidence 
accompanying the wave of decolonisation throughout the 1950s and 1960s. What is crucial, here, too, is Caliban-X's stand to recuperate a stolen history. He recognises, like Césaire, how his own culture and heritage were razed from the collective memory of an enslaved and transported African diaspora and it is this that he will strive to re-discover, value and honour.

Césaire adds an interesting interpolation, a wholly new scene, at the start of Act Two, where Ariel, significantly identified as a mulatto slave in the list of characters, comes to warn Caliban that Prospero is planning "d'épouvantables vengeances" (36) ["appalling acts of revenge" (26)] against him. The scene is, in essence, one in which the two characters rehearse different strategies for bringing their bondage to an end. Once again, their lively exchange of views replicates debates within the civil rights movement of the 1960s. Césaire said in an interview:

My text [...] was greatly influenced by the preoccupations I had at that particular time. As I was thinking very much about a play concerning the United States, inevitably, the points of reference became American. [...] There is the violent and the non-violent attitude. There are Martin Luther King and Malcolm X and the Black Panthers. ${ }^{33}$

Caliban has already cast himself as $\mathrm{X}$ and, needless to say, adopts the more militant position, demanding "Freedom now!" Interestingly, Césaire renders this famous Black Power cry in English. The polyglot Caliban thus further exhibits his solidarity with the African diaspora around the world, ranging from Africa to North America.

Ariel provides another perspective which amounts to "Ni violence, ni soumission" (37) ["Neither violence, nor submission" (27)] but is rather one of peaceful resistance entered into in order to trouble Prospero's calm "pour qu'une conscience naisse à [lui]" (37) ["so that a conscience can well up inside him" (27)] with the intended result that he will finally acknowledge his own injustice. He adds, in a striking echo of Martin Luther King's famous "I have a dream" speech:

J'ai souvent fait le rêve exaltant qu'un jour, Prospero, toi et moi, nous entreprendrions, frères associés, de bâtir un monde merveilleux, chacun apportant en contribution ses qualités propres : patience, vitalité, amour, volonté aussi, et rigueur, sans compter les quelques bouffées de rêve sans quoi l'humanité périrait d'asphyxie. (38)

I've often dreamt a rapturous dream that one day Prospero, you and I would set out as brothers to build a wonderful world, each contributing his own qualities: patience, vitality, love, will power too, and rigour, not to mention the eddying dreams without which humanity would suffocate to death. (28)

33. Cited in Robert P. Smith and Robert J. Hudson, "Evoking Caliban: Césaire's Response to Shakespeare," CLA Journal, vol. 35, n 4, 1992, p. 387-399, p. 394. 
Caliban scoffs at Ariel's credulousness:

Dis donc, mon petit Ariel, des fois, je me demande sit tu n'es pas cinglé! Que la conscience naisse à Prospero? Autant se mettre devant une pierre et attendre qu'il lui pousse des fleurs! [...] Tu n'as rien compris à Prospero. C'est pas un type à collaborer. C'est un mec qui ne se sent que s'il écrase quelqu'un. Un écraseur, un broyeur, voilà le genre! Et tu parles de fraternité ! (37-38)

Listen my sweet Ariel, I sometimes wonder if you aren't cracked. So that a conscience can well up inside Prospero? You might as well wait for a stone to burst into bloom! [...] You don't understand Prospero at all. He's not the collaborative type. He's a man who only feels alive when he's crushing someone. A crusher, a grinder to pulp, that's what he is! And you talk of brotherhood! (28)

The militant Caliban believes the dreamy Ariel is a dupe. Once again, with a striking economy, Césaire pays short shrift to the Christian-humanist narrative of reconciliation (via an imposed penance and then contrition) willed by Prospero in Shakespeare's play. Caliban is prepared for a violent armed struggle akin to those waged by the Mau Mau or the ANC, saying:

Mieux vaut la mort que l'humiliation et l'injustice... D'ailleurs, de toute manière, le dernier mot m'appartiendra... À moins qu'il n'appartienne au néant. Le jour où j'aurai le sentiment que tout est perdu, laisse-moi voler quelques barils de ta poudre infernale, et cette île, mon bien, mon œuvre, du haut de l'empyrée où tu aimes planer, tu la verras sauter dans les airs, avec, je l'espère, Prospero et moi dans les débris. (38)

Better death than humiliation and injustice... Besides the last word shall be mine. Unless it belongs to nothingness. The day I feel all's lost, just let me filch a few barrels of your infernal powder and - from high in the empyrean where you love to soar - you will see this isle, my inheritance, my work, all blown sky high, with, I hope, Prospero and me amongst the debris. (28)

Such words now seem grimly prophetic of suicide bombings and campaigns of terror but they also identify the despair and desparation of the perpetrators and the terrible cost of stripping the wretched of the earth of their dignity, robbing them of their birthright and making them fear for their very existence, especially (and most usually) in a colonial situation, itself underpinned by violence. It is within this incredibly highstakes situation, that the racial difference between the two slaves must be understood and considered. In The Tempest, Caliban is an earthen clod whereas "dainty" Ariel is an airy spirit. Césaire seizes upon this difference but racializes it, too. Historically, Martinique had more mulattoes than whites and, as ever, in colonial societies where the white ruling class sought to inculcate its values and sought to impress upon its subjects that its culture and skin colour were the ideals, the paleness of one's skin and the proximity of one's position to the white rulers became an important 
factor in determining one's position in the social hierarchy. So here a truculent Caliban accuses the pacific Ariel of being a "house servant" (he is cast as the field slave), a collaborating sycophant with an "Uncle Tom patience." Césaire does not shy away from projecting the racialized differences and tensions residing within colonial (and post-colonial) societies, not least his own. Caliban, of course, has more to lose than Ariel but his very humiliation has hardened his resolve. Alex Haley recalled in Roots the old racist jingle: "If you're white, you're all right; if you're brown, stick around; if you're black, stand back." ${ }^{34}$

In the eyes of the monological Prospero, "Par [1']insubordination [de Caliban], c'est tout l'ordre du monde qu'il remet en cause" (71) "[Caliban's] insubordination calls into doubt the entire order of the world" (47)].

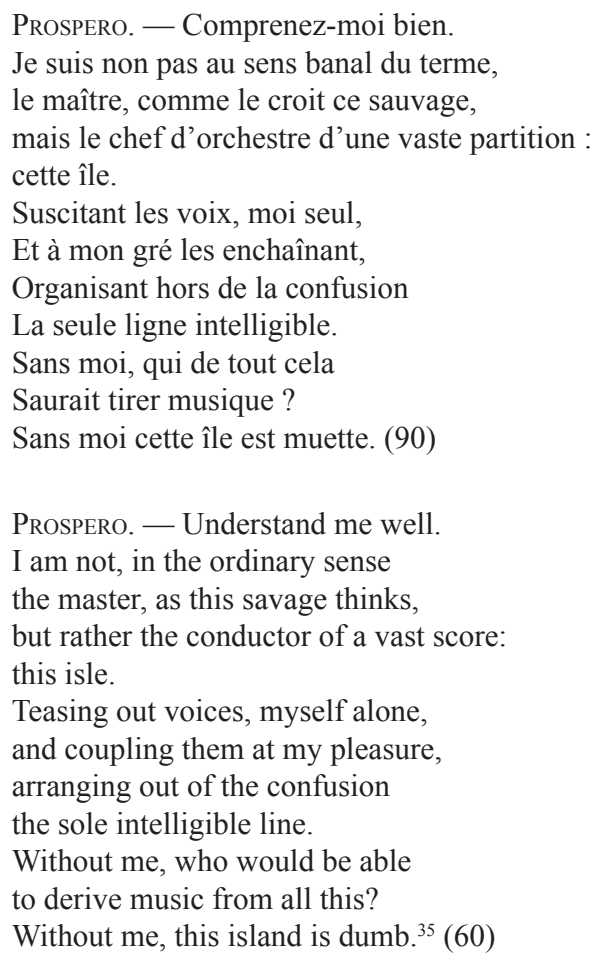

34. Lucy Rix, op. cit., p. 237-238, discusses the drive towards self "whitening" as one of the most insidious obstacles to decolonization in Martinique and how mulattos with their peau chappés (escape skins) sought nothing but the ideal of assimilating into white French culture. The racial ideology, based on the association of the idea of freedom with resemblance, was deeply seated in not just the white but also within the mulatto and black communities as well.

35. In his Course in General Linguistics, Ferdinand de Saussure (posthumous inspirer of Structuralism) conceives of language as composed of the overarching general structure, langue, and localized, contextual utterances he calls parole. He provides the metaphor of the 
Chris Tiffin and Alan Lawson argue that, "Imperial textuality appropriates, distorts, erases, but it also contains. ${ }^{36}$ The imperial project contains cultures/subjects in order to control them, but no former colony is as simply circumscribed as colonial discourse would have it: each postcolonial political, historical, linguistic, and cultural situation inevitably becomes much more convoluted than is figured by the coloniser. In truth, it is Prospero who is enfeebled by his monoglot sclerosis. His rigid cultural position does not brook translation. He cannot discourse - his is a dialogue of the deaf - he can only dictate. Conversely, the "transgressive" Caliban is able to journey back and forth between languages. Empowered, he understands Prospero, not vice-versa.

By the end of the play, Caliban has made multiple claims to African "Uhuru," Black Power's "Freedom now" and an internationalist call to "Liberty ohay liberty" which transcends all boundaries. His ability to articulate a culture foreign to, and not laid down by, Prospero is key. Prospero uses language to close down consciousness. Concerning Caliban, his language constantly negates, denies and demonises: "brute savage," "beast," "sorcerer," etc, whilst Caliban's linguistic identity, his African utterances, are dismissed as "Encore une remontée de ton langage barbare" (24) ["yet another return to your savage tongue" (19)]. Whereas Caliban asserts and affirms potential and otherness, Prospero refuses dialogue: "Je ne t'ai pas appelé pour discuter!" (27) ["I did not summon you here to argue" (21)]. He is portrayed as a sadistic power wielder who had dreamt of establishing a colonial empire even before leaving Italy and who is bereft of his original's christianised goodwill: "Si tu rouspètes, la trique" (27) ["If you grumble you shall be thrashed" (21)]. ${ }^{37}$ Césaire focuses on Prospero's

orchestra to elucidate his concept. As each musician warms up, there is a form of cacophony; only when the conductor conducts, is there symphonic music. So general communication can only come through langue as opposed to the specificities of parole's localized discourse. See Ferdinand de Saussure, Course in General Linguistics, Trans. Roy Harris, La Salle, Illinois, Open Court, 1983. Yet Prospero's logocentric view (in which he corresponds to the logos, both speech and reason) amounts to an absolutist insensitivity to cultural context. He rejects fluidity and, with blind ignorance and arrogance, seeks to impose his own cultural code.

36. Chris Tiffin and Alan Lawson, Eds., De-Scribing Empire: Post-Colonialism and Textuality, London, Routledge, 1994, p. 6.

37. Indeed, in an exciting addition to the original plot, the scientific Prospero sneers in recollecting his near-persecution at the hands of the Inquisition ("êtres de nuit" (21) ["creatures of darkness" (17)]) who wished to try him over charges of necromancy and sorcery. Césaire casts Gonzalo as a pious buffoon whose catechism lesson on the difference between an act of contrition and an act of attrition satirically evokes the Christian will to reconciliation and forgiveness so central to The Tempest. His later attempted exorcism of Caliban, which the latter meets with laughter, and then the handing him over to the "bras séculier" (86) ["secular arm" (56)], ie Prospero, to do with as he will, chillingly calls to mind the complicity of the Church in the ruthless execution of the colonial enterprise and the persecution of indigenous peoples under the guise of saving their souls (as recalled in the murals of Diego Rivera in Mexico City). 
magic - a physical control over others - in this strictly limited sense. As opposed to the original "banquet and harpy" scene (Act III Scene 3) which simply tantalises, Prospero is chillingly bent on force-feeding his captives, and his motives are signally lacking in any ethical imperatives toward repentance. While Prospero may claim "Je suis la Puissance" (44) ["I am Power" (32)], his material might resides in technological know-how and the machinery of repression. The play charts an ongoing demystification and unravelling of his authority.

As $A$ tempest reaches its climax, Caliban recites a long litany of abuses and injustices forced upon him:

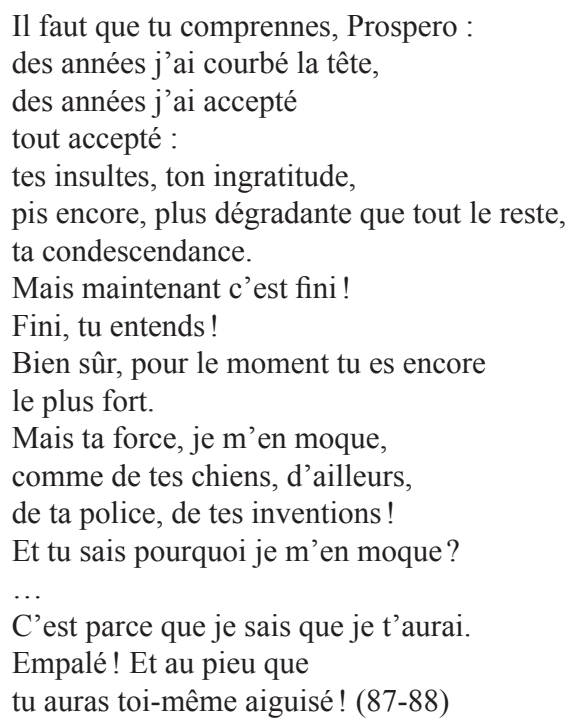

You must understand, Prospero:

for years I bowed my head, for years I stomached it, stomached all of it: your insults, your ingratitude, and worst of all, more degrading than all the rest, your condescension.

But now it's over!

Over, do you hear!

Of course, for the moment you're still

the stronger.

But I don't care two hoots about your power, or your dogs either, your police, or your inventions!

And do you know why I don't care?

It's because I know I'll have you! 
You'll be impaled! And on a stake

you'll have sharpened yourself! ${ }^{38}(57-58)$

In an inspired response to Shakespeare's mage's magic, Césaire's Caliban identifies Prospero's illusions with spreading a deceitful false consciousness about the state of the world, imposing on Caliban a disabling belief in his own underdevelopment and incompetence. ${ }^{39}$ The speech is a culmination of Caliban's efforts, established from his first entry, to rise up above oppression and resurrect an authentic black culture and history. Gilbert and Tompkins write,

Historical recuperation is one of the crucial aims and effects of many post-colonial plays, which frequently tell the other side of the conquering whites' story in order to contest the official version of history that is preserved in imperialist texts. Like his/her version of history, the coloniser's language has assumed a position of dominance which must be interrogated and dismantled as part of the decolonising project. ${ }^{40}$

Caliban has forced Prospero to look full square upon the charade of his colonial "mission" and when the latter warns him that he is heading towards suicidal perdition, Caliban tells him he hates him. Prospero answers in kind:

Eh bien moi aussi je te hais!

Car tu es celui par qui pour

la première fois j'ai douté de

moi-même. (90)

Well I hate you as well!

For you are the one who

made me doubt myself

for the first time. (59)

His ambivalence emphasises the shattered authority that has been steadily increasing throughout the play. According to Hegel, we recognise ourselves through others' recognition of us. Caliban does not grant this consensual recognition. A fissure rends the colonial veil. Whereas, in The Tempest, Prospero leaves the island to return to Naples, conveniently bestowing forgiveness on all and sundry - even if there is no contrition from Antonio - and with an imminent marriage between Miranda and Ferdinand symbolising a re-soldered alliance between estranged ruling houses, here he remains. Just as Césaire's Ariel sings, “Rien n'est, tout

38. See the citation at the start of this article to see how this speech continues.

39. According to Michel Giraud, "Dialectics of Descent and Phenotypes in Racial Classification in Martinique," in Richard D.E. Burton and Fred Reno (eds.), French and West Indian: Martinique, Guadaloupe and French Guiana Today, London, Macmillan, 1995, p. 75-85, racism in Martinique was deeply internalized.

40. Gilbert and Tompkins, op. cit., p. 12. 
devient" (30) ["Nothing is, all becomes" (23)], so post-colonial theatre configures "process, not arrival." ${ }^{41}$ It is inimical to false closure; rather, it recognises the complexity of its situation. Prospero, the old colonialist, is left listless and aged, alone on the island, raging against the encroachment of nature, roaring out for Caliban but unable to untangle the complexity of his relationship with him beyond: "Toi-Moi! Moi-Toi!" (92) ["YouMe! Me-You!" (61)] But the mutuality of this dialectic no longer holds. Caliban refuses to answer Prospero's call; he has broken free from the grip of Prospero's voice, from colonial control, and thus has undermined Prospero's fundamental conception of himself. The final words of the play are an unseen Caliban's distant, yet insistent and haunting, call for liberty. Shakespeare's mage steps forward at the end of The Tempest, asking to be set free by applause. Here, there is no such recognition. Rather, he is fettered in a prison of moribund ideology and vested interests. Prospero's failure to leave the island also indicates Césaire's recognition that whether decolonised or not, the grasp of colonialism (and, crucially, neo-colonialism) will not be relinquished so easily.

Steve Almquist writes: "Césaire's representation of Caliban produces an Africanized figure that embodies the complexity of the diasporic African in the middle of the twentieth century." ${ }^{\prime 2}$ It is my contention that the resurrection and resistance of Caliban is founded upon the African cultural resonances in the play: "Uhuru," Shango, "Oo-en-day," "Macaya." It is to these that Caliban owes allegiance and not to imposed western ideologies. Like Malcolm, he calls himself "X," identifies his dispossession, the fate of the enslaved African diaspora, and casts off the slough of abjection as he reclaims and refashions his cultural identity, "fighting for survival," in Marley's words, "in the heart of the Caribbean." ${ }^{43}$ Caliban twice invokes Shango, the Yoruba god of thunder and lightning and the owner of the Bata drums. Césaire identifies Shango as a great god of heaven who is very violent but who is fundamentally benevolent, renewing the face of the earth. Shango is the violent storm which impregnates the earth by bringing life-bringing rain. Shakespeare's western tempest is countered by an African one. ${ }^{44}$

41. Helen Tiffin, "Post-colonial literatures and counter-discourse," in Kunapipi vol. 9, n 3, p. 17-34, p. 17. Tiffin adjudges that, "Decolonization is process, not arrival."

42. Almquist, op. cit., p. 591.

43. Bob Marley and the Wailers, Buffalo Soldier, 1980, on the posthumously released Confrontation LP, Tuff Gong/Island Records, 1983.

44. The Yoruba are a people of western Nigeria and neighbouring regions. A syncretistic religion of Shango is widespread across the Caribbean and in Brazil. In La Tragédie du Roi Christophe, Henri Christophe, who wished to honour and restore the grandeur of his people, represents Shango. Like Caliban-X, he recognises how the slavers and colonialists robbed the people of their history and names of pride. Aimé Césaire, La Tragédie du Roi Christophe, Paris, Présence Africaine, 1970. 
A crucial interpellation into Shakespeare's play comes as Une tempête speeds towards its climax. Eshu, the African trickster devil-god "Dieu pour les amis, diable pour les ennemis" (68) ["God to my friends, Devil to my enemies" (45)], erupts into Prospero's masque - anti-masque par excellence to all the stilted, ongoing decorum of the classical goddesses. His lewdness and sexual predatoriness - "de son pénis il frappe" (70) ["with his penis he smites" (46)] is an ironic exposure of white paranoia and demonization. Cocking a snook at Prospero, Eshu is not part of the colonialist's script. He re-appropriates a vivid black identity by using negative stereotype, in a manner analogous to the political use of such terms as "dreadlock" or "queer," and revelling in its otherness. Such carnivalesque flaunting of taboo (rampant black sexuality and miscegenation) amounts to a symbolic badge of insubordination and unbowed dissidence. The western pantheon is dispersed and routed by such "vulgarity." Eshu stands for the supplanted spirit of Africa returning, superabundant and irrepressible. ${ }^{45}$

Crucially, although beleaguered by the illusory ideologies of colonialism, Caliban remains true to his own culture and beliefs, living a symbiotic partnership with nature (personified as his mother Sycorax):

\author{
Sycorax ma mère! \\ Serpent! Pluie! Éclairs! \\ Et je te retrouve partout : \\ Dans l'œil de la mare qui me regarde, sans ciller, \\ à travers les scirpes. \\ Dans le geste de la racine tordue et son bond qui attend. \\ Dans la nuit, la toute-voyante aveugle, \\ la toute-flaireuse sans naseaux! (26) \\ Sycorax my mother! \\ Serpent! Rain! Lightning! \\ And I find you everywhere! \\ In the eye of the pond, which stares at me, unblinking, \\ through the rushes.
}

\begin{abstract}
45. See Gilbert and Tompkins, op. cit., p. 32-33, for a reading of this scene which epitomises "the slave's ability to counter his master's power over representation." "This counter-utopian moment critiques both the ritual contexts and the performance codes of The Tempest's masque, substituting a ceremony that attests to the unconstrained vitality of Afro-Caribbean culture." See Rix, op. cit., p. 240, where she writes of Césaire's appropriation of surrealism in his arsenal of cultural resistance. Surrealism "aimed to shock the prim bourgeoisie with a production of humorous, vulgar gestures that attempted to undermine the validity and authority of high-brow Western culture." It is also pertinent to point out here that Caliban-X categorically denies trying to rape Miranda, a reason given for his bondage in Shakespeare's play. Rather he says to Prospero: "Dis-donc, vieux bouc, tu me prêtes tes idées libidineuses" (27) ["Listen, old goat, you've foisted your own lustful cravings on me (21)]." In Shakespeare's original, Caliban is cast as an unbridled wild man, the wild man being the very image of desire.
\end{abstract}


In the gesture of the twisted root with coiled spring.

In the blinded all-seeing night,

the nostril-less all-smelling night! (20)

It is he, rather than Shakespeare's poet-mage, who is the most effective of verbal artificers. ("The isle is full of noises" speech, uttered by Caliban, is of course, one of the most beautiful and stirring in The Tempest.)

Césaire celebrates Caribbean and African ecology throughout. ${ }^{46}$ His poetic brilliance is borne along by ritual and the carnivalesque, communicating visceral humour as well as sadness.

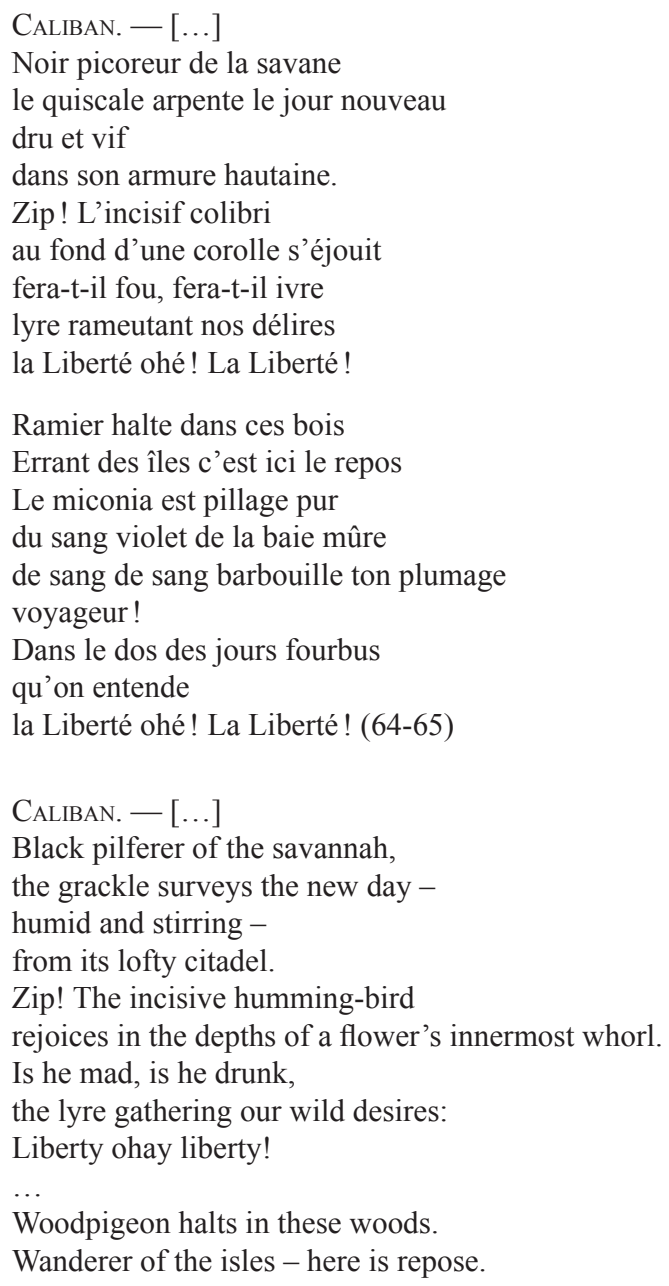

46. When reminded of being imprisoned in the cloven pine, Ariel dreams of having metamorphosed into a tree, Ovid-style. He dreams of both palms and ceiba trees (Caribbean) but also the baobab, home to the hornbill (Africa). 


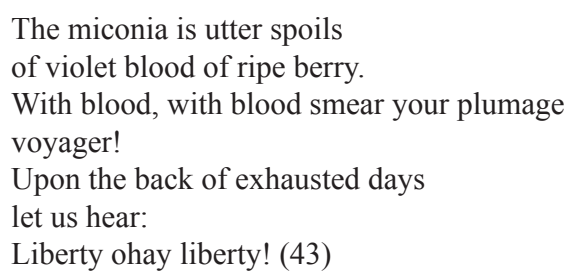

This song of Caliban's resonates with Shakespeare's Ariel's "Where the bee sucks there suck I" (the humming-bird rejoicing in the flower's innermost whorl) and exemplifies Césaire's creative refashioning of The Tempest into a Caribbean context.

Césaire did not generally write in creole but "marooned" himself from metropolitan French, refashioning a new voice in a manner congruent with Bill Ashcroft et al.'s notion of Britain's erstwhile Empire "writing back." ${ }^{47}$ The maroons were runaway slaves. By analogy, he sought to break the fetters of colonialist discourse. Césaire punned that he would pluck the "marrons du feu," literally plucking the sweet-chestnuts from the fire but also symbolically rising up against imperialist strictures. Here the mystification and assumptions of the colonially projected Tempest are met head on and the colonial form is hybridised with the introduction of African and English languages and African and Caribbean ritual and rhythm. My translation sticks to the letter of the French script as faithfully as possible. Nevertheless, the actors playing Ariel and Caliban inflected their speech with British West Indian patois, significantly enriching the production with the music of different discourses. Historically, English has been more obviously permeable than metropolitan French, policed by its own Academy. (Césaire himself was famously the brilliant scholarship boy from the Antilles who spoke an elegant formal French, even conjugating the imperfect subjunctive in conversation.)

Over the years, the late prophet of negritude was criticised by other black post-colonial writers (e.g. Wole Soyinka) and the disciples of "créolité" for his allegiance to abstraction (some overarching Africanness) and for failing to recognise the authentic plurality of voices in the Caribbean. Césaire wrote predominantly in classical French. Yet, absent though creole might be from Une tempête, this play cherishes the local just as it springs from a deep love of Africa, the faith and rock of the black diaspora. Furthermore, Césaire's negritude is grounded in a profound historical consciousness which identifies a common past of suffering experienced by the African diaspora worldwide at the hands of imperialists and slavers. Caliban the hero delivers a clarion call for justice and solidarity. 
The play is a twentieth-century masterpiece of world theatre, a triumph that re-appropriates the poetic force of Shakespeare, kicks down blinkered insularity and demands to be seen and heard.

Philip Crispin

University of Hull, England 